\title{
Unused agricultural land in Russia - the significance and impact on the economy of agricultural production
}

\author{
G.A. Iovlev ${ }^{1, *}$, I.I. Goldina ${ }^{1}$, and V.S. Zorkov ${ }^{1}$ \\ ${ }^{1}$ Ural state agrarian University, 620075 Yekaterinburg, Russia
}

\begin{abstract}
The problems of unused lands began to be dealt with almost immediately after the introduction of economic reforms. As a result of economic reforms, privatization in agriculture, the main agricultural enterprises - state farms, collective farms changed the form of ownership, and enterprises were also subdivided. As a result, a significant number of private enterprises, joint-stock companies of various types, agricultural cooperatives, peasant farms and private subsidiary farms appeared. Often, as a result of division and fragmentation, newly created enterprises found themselves without the appropriate material and technical base, and more often without financial resources. The next result of economic reforms was a spontaneous increase in the disparity of prices for agricultural and industrial products. As a result, it became impossible to carry out work on cultivation of agricultural crops on all available areas or to carry out work with violation of the technology of agricultural crops cultivation. As a result, the volume of acreage decreased, technologies and crop rotations were disrupted, and all this affected the financial condition of newly formed agricultural organizations. Another important reason that affects the withdrawal of agricultural land from turnover is the outflow of population from small settlements, they simply disappear. Land around these localities becomes "problematic" and is taken out of turnover. It should be noted that the next reason for the withdrawal of land from turnover is its low fertility and the presence of natural anomalies that require large material costs for the cultivation of agricultural crops. Therefore, the introduction of unused agricultural land into turnover provides for an increase in agricultural production, reducing unemployment in rural areas, and most importantly ensuring state food security.
\end{abstract}

\section{Introduction}

This research is conducted under the theme "Methods of evaluating the effectiveness of involvement of unused agricultural land in agricultural use" proposed by the Informatization Department of the Ministry of Agriculture of Russia to higher education institutions under the Ministry of Agriculture of the Russian Federation, at the expense of means of the Federal budget under the order of the Ministry of Agriculture in 2021.

\footnotetext{
*Corresponding author: gri-iovlev@yandex.ru
} 
The problem of unused agricultural land is very relevant. During the period of reforms (since 1990), about 131 million hectares of arable land were withdrawn from agricultural turnover, the area under grain decreased by 2.5 times, and under forage crops by 4.5 times.

This problem has been reflected in the research of Russian researchers since the very beginning of reforms in the Russian economy, including in agriculture. It should be noted that in different periods, researchers considered the problem of the emergence of unused land from different points of view.

In the initial period (until 2000), they considered from the point of view of the correctness and objectivity of the assessment of agricultural land for sale (Belova T.N., Uzun V.Ya, Arashukova V.P); in the period from 2000 to 2010, research was conducted in the direction of preparing recommendations for bringing the constituent documents that appeared during this time of various economic formations, in accordance with the requirements of the legislation of Russia (Zavorotin E.F., Nechaev V.N., Barsukova G.N., Chemerichko A.V.); since 2010, research has been aimed at studying the reasons for withdrawing agricultural land from turnover, justifying the need to enter land into agricultural turnover, research and development of technologies that ensure the introduction of unused land with minimal costs and effective use of technologies in the future (Nikiforova E.O., Bondarenko O.V., Khairbekov A.U., Mironova A.V., Liskin I.V., Afonina I.I.).

In their research, the authors set the task to determine the main reasons for the appearance of unused or abandoned agricultural land, the impact of these reasons on the withdrawal of these lands from turnover and the need to enter unused land into turnover.

\section{Materials and methods}

The research on this topic is based on the materials of the Federal State Statistics Service on agriculture, socio-economic indicators of Russian regions, from statistical collections for 2002-2019, using research of leading Russian scientists. The study was performed using normative, statistical, expert assessments, program-target, economic and mathematical methods.

Results and discussion. In order to increase the efficiency of agricultural production, increase its profitability, and ensure food security of the state, there is a need to involve unused agricultural land in agricultural turnover.

For a comparative analysis of production volumes and availability of agricultural land, consider the data presented in table 1.

Table 1. Indicators that characterize agricultural production in Russia

\begin{tabular}{|l|c|c|c|c|c|c|c|c|}
\hline \multicolumn{1}{|c|}{ Indicators/ Years } \\
\hline 2000 & 2005 & 2010 & 2015 & 2016 & 2017 & 2018 & 2019 & 2020 \\
\hline \multicolumn{7}{|c|}{ Total acreage, thousand ha (households of all categories/agricultural organizations) } \\
\hline 84670 & 75837 & 74861 & 78635 & 79312 & 80049 & 79634 & 79880 & 79630 \\
\hline 74192 & 60472 & 56104 & 55101 & 54723 & 54437 & 53579 & 53253 & 52538 \\
\hline \multicolumn{7}{|c|}{ Area of grain and leguminous crops, thousand ha (farms of all categories/agricultural } \\
\hline \multicolumn{8}{|c|}{ organizations) } \\
\hline 47176 & 43174 & 43203 & 46609 & 47100 & 47705 & 46339 & 46660 & 47981 \\
\hline 40675 & 34698 & 32048 & 32052 & 31933 & 31618 & 30250 & 30309 & 30905 \\
\hline \multicolumn{7}{|c|}{ Area of forage crops, thousand ha (farms of all categories/agricultural organizations) } \\
\hline 28899 & 21610 & 18046 & 16993 & 16425 & 16342 & 16124 & 15417 & 14435 \\
\hline 26528 & 19508 & 15485 & 13448 & 12768 & 12518 & 12243 & 11600 & 10743 \\
\hline \multicolumn{7}{|c|}{ Area of potato, thousand ha (households of all categories/agricultural organizations) } \\
\hline 2834 & 2277 & 1948 & 1562 & 1441 & 1350 & 1325 & 1255 & 1192 \\
\hline 231 & 154 & 233 & 207 & 195 & 171 & 174 & 170 & 154 \\
\hline
\end{tabular}




\begin{tabular}{|c|c|c|c|c|c|c|c|c|}
\hline \multicolumn{9}{|c|}{$\begin{array}{c}\begin{array}{c}\text { Gross yield of grain and leguminous crops, thousand tons (farms of all categories/agricultural } \\
\text { organizations) }\end{array}\end{array}$} \\
\hline 65420 & 77803 & 61007 & 104729 & 120677 & 135539 & 113255 & 121200 & \\
\hline 59418 & 62727 & 46994 & 76181 & 86179 & 94969 & 79540 & 84905 & \\
\hline \multicolumn{9}{|c|}{ Gross potato yield, thousand ha (households of all categories/agricultural organizations) } \\
\hline 29465 & 28137 & 18498 & 25406 & 22463 & 21708 & 22395 & 22073 & \\
\hline 2222 & 2354 & 2213 & 4656 & 4210 & 4233 & 4317 & 4629 & \\
\hline \multicolumn{9}{|c|}{ Gross forage crop yield, thousand ha (households of all categories/agricultural organizations) } \\
\hline 15940 & 12789 & 8953 & 11164 & 12581 & 11875 & 10881 & 10243 & \\
\hline 14477 & 10756 & 6795 & 7021 & 7712 & 6770 & 6092 & 5501 & \\
\hline \multicolumn{9}{|c|}{$\begin{array}{l}\text { Gross forage crop yield, thousand ha (households of all categories/agricultural organizations) - } \\
\text { grain crops, haylage }\end{array}$} \\
\hline 69346 & 61989 & 39255 & 52117 & 52409 & 56650 & 50780 & 51749 & \\
\hline 68888 & 60336 & 38064 & 49406 & 49613 & 53200 & 47431 & 48304 & \\
\hline \multicolumn{9}{|c|}{ Yield of grain and leguminous crops, c/ ha (farms of all categories/agricultural organizations) } \\
\hline 15.6 & 18.5 & 18.3 & 23.7 & 26.2 & 29.2 & 25.4 & 26.7 & \\
\hline 15.9 & 18.8 & 19.0 & 25.0 & 27.6 & 31.0 & 27.2 & & \\
\hline \multicolumn{9}{|c|}{ Yield of potato. c/ha (households of all categories/agricultural organizations) } \\
\hline 105 & 124 & 100 & 164 & 158 & 163 & 170 & 178 & \\
\hline 104 & 156 & 136 & 234 & 226 & 258 & 256 & & \\
\hline \multicolumn{9}{|c|}{ Yield of forage crops. c/ha (households of all categories/agricultural organizations) - hay } \\
\hline 15.5 & 16.4 & 13.7 & 16.6 & 18.9 & 18.7 & 17.6 & 18.7 & \\
\hline 15.2 & 15.7 & 13.5 & 16.3 & 18.8 & 18.1 & 17.0 & & \\
\hline \multicolumn{9}{|c|}{$\begin{array}{l}\text { Yield of forage crops. c/ha (households of all categories/agricultural organizations) - grain crops. } \\
\text { haylage }\end{array}$} \\
\hline 89 & 96.5 & 75 & 89 & 93 & 97.5 & 89.5 & 92 & \\
\hline 89 & 97 & 85 & 90 & 94 & 98.5 & 90 & & \\
\hline \multicolumn{9}{|c|}{ Agricultural products. billion rub. (households of all categories/agricultural organizations) } \\
\hline 586 & 1253.2 & 2390.1 & 4031.1 & 4794.6 & 5112.3 & 5109.5 & 5348.8 & 5801.4 \\
\hline 249.8 & 573.5 & 1093.1 & 2083 & 2588.6 & 2818.4 & 2818.5 & 3022.1 & 3348.4 \\
\hline
\end{tabular}

The table was developed by the authors using statistical data [1].

Data in table 1 shows that the total cultivated area between 2000 and 2020 dropped to 5040 thousand ha if sown area in agricultural organizations during this period decreased by 21654 thousand ha, in personal subsidiary plots (PSP), peasant farms (PF), private households increased by 16614 thousand ha. But the main decrease in acreage was allowed in the period from 1990 to 2000 and amounted to 33035 thousand ha. In agricultural organizations, the decrease was 41096 thousand ha, in PSP, PF, personal farmsteads increased by 8061 thousand ha. [1] The presented material shows that there was a redistribution of acreage between agricultural organizations of collective ownership on the one hand and PSP, and PF on the other. However, since 1990, 38075 thousand ha of acreage have been withdrawn from agricultural turnover.

The decrease in acreage in crop production directly affects the animal husbandry subsector. Thus, the acreage under forage crops has decreased by 14464 thousand ha over the past 20 years, i.e. almost twice. As a result, the number of cattle during this period decreased by 9393.8 thousand heads, including cows by 4778.4 thousand heads [1].

To justify the reasons for the withdrawal of agricultural land from agricultural turnover, consider the dynamics of changes in the crop area in the context of Federal districts of Russia, the data are presented in table 2.

Table 2. Acreage by Federal districts of the Russian Federation, thousand ha

\begin{tabular}{|l|l|l|l|l|l|l|}
\hline \multicolumn{7}{|c|}{ Federal districts/Years } \\
\hline 2000 & 2005 & 2010 & 2015 & 2016 & 2017 & 2018 \\
\hline \multicolumn{7}{|c|}{ Central FD } \\
\hline
\end{tabular}




\begin{tabular}{|l|c|c|c|c|c|c|}
\hline 16721 & 13990,9 & 13783 & 15151,7 & 15225,2 & 15530,6 & 15367 \\
\hline \multicolumn{7}{|c|}{ Northwestern FD } \\
\hline 2584.1 & 1840.5 & 1489.9 & 1401.1 & 1423.6 & 1404.6 & 1383.2 \\
\hline \multicolumn{7}{|c|}{ Southern FD } \\
\hline $10721.4^{*}$ & 11202.2 & 11292 & 12314.5 & 12506.1 & 12653 & 12853.5 \\
\hline \multicolumn{7}{|c|}{ North Caucasus FD } \\
\hline $3829.4^{*}$ & 3832.2 & 3980.9 & 4272.9 & 4356.3 & 4381.3 & 4430.6 \\
\hline \multicolumn{7}{|c|}{ Volga FD } \\
\hline 27351.3 & 23517.7 & 23133.7 & 23629 & 23819.2 & 23906.6 & 23922.9 \\
\hline \multicolumn{7}{|c|}{ Ural FD } \\
\hline 6027.6 & 4997.3 & 5330.4 & 5128.6 & 5146.1 & 5159 & 5150.5 \\
\hline \multicolumn{7}{|c|}{ Siberian FD } \\
\hline 16738.8 & 14758.0 & 14077.4 & 14520.8 & 14572.9 & 14628.3 & 14081.3 \\
\hline \multicolumn{7}{|c|}{ Far Eastern FD } \\
\hline 1431.5 & 1680.2 & 1779 & 2216.2 & 2262.6 & 2385.3 & 2444.8 \\
\hline
\end{tabular}

* Acreage of the Southern FD and North Caucasus FD in 2000 are defined by calculation from statistical data on crop areas of the Southern FD in 2000 acreage of subjects ceded to 2005 in the North Caucasian FD are deducted.

The table was developed by the authors using statistical data [2-6].

In different Federal districts, the situation with the preservation of the land fund is different. In the Central FD, the decrease over twenty years was 1354 thousand ha or $0.33 \%$ per year, in the Southern FD and the North Caucasus FD there was an increase of 2132.1 thousand ha and 601.2 thousand ha, respectively, in the Far Eastern FD an increase of 1013.3 thousand ha. In the Volga FD, the acreage decreased by 3428.4 thousand ha, in the Siberian FD - 2657.5 thousand ha, in the Ural FD and Northwestern FD the decrease was 877.1 thousand ha and 1200.9 thousand ha, respectively.

The significant reduction of the volume of acreage in 2000 made by Northwestern region $-46 ., 5 \%$, Siberian FD - 15.9\%, Ural FD - 14.5\%, Volga FD - 12.5\%. The decrease in the Central FD was $8.1 \%$ of the volume of acreage in 2000 .

After analyzing the data from table 2 and based on our own research, we can conclude about the reasons for the withdrawal of agricultural land from turnover.

1. In our opinion, the main factor influencing the withdrawal of agricultural land from turnover is the bioclimatic potential (BCP).

2. The second, no less important factor is the economic downturn in the country's economy, especially in agriculture.

3. The third factor was the lack of appropriate types of agricultural machinery that can work effectively on small areas and the ability of private agricultural organizations to purchase this equipment.

4. Incorrect methodological approach to privatization in agriculture. The idea of unprofitability and low profitability of agricultural production in large areas was put forward.

Let us consider in more detail the influence of bioclimatic potential on the efficiency of agricultural production, crop production, and on the dynamics of changes in acreage.

A simple definition of the bioclimatic potential is the following: a complex indicator that characterizes the number of positive temperatures during the growing season, the amount of precipitation and moisture reserves in the soil, natural soil fertility, taking into account humus reserves, soil structure and mineral element reserves in the soil for a particular region. Serious research of the BCP was conducted by domestic and foreign scientists, such as V.Ya. Uzun [7,8], A.V. Gordeev, A.D. Kleshchenko, B.A. Chernyakov et al. [9], A.L. Ivanov, A.A. Zavalin, M.S. Kuznetsov et al. [10], L.N. Ermakova, N.I. Tolmacheva, E.A. Bezmaternykh [11], S.V. Krasheninnikov [12], S.V. Shchukin, A.I. Golubeva, V.I. Dorokhova et al. [13], I.I. Goldina, V.S. Zorkov [14], et al. [15-17]. 
In our study, we will consider the impact of BCP on the dynamics of changes in acreage, on the yield of grain crops, depending on the bioclimatic potential of a region. For comparison, we will take two regions of the Southern Federal district with different indicators of BCP, as the Federal district that increased acreage since 2000, and two regions from the Central Federal district that allowed a decrease in acreage. In the first case, it is the Krasnodar territory and the Volgograd region, in the second - the Kursk region and the Kostroma region [18]. The results of the analysis are shown in Fig. 1. We will analyze the indicators using indexes. For the "basic" indicators, we will take acreage of the regions in 2000; grain yield in the Krasnodar territory in 2000.

From the data presented in Fig. 1 the increase in acreage, compared with 2000, in the Krasnodar territory amounted to $0.5 \%$ by 2018 . The decrease was made in the period from 2000 to 2005 and amounted to $3.7 \%$, since 2005 there has been an increase in acreage from 0.3 to $2.4 \%$ per year. The yield for the period from 2000 to 2018 in the Krasnodar territory increased by 1.5 times and amounted to $52.9 \mathrm{c} / \mathrm{ha}$. Another situation with changes in the volume of acreage occurred in the Volgograd region (the lowest BCP in the Southern FD). The increase in acreage by 2018 was $21.5 \%$, while the decrease from 2005 to 2010 was $8.6 \%$. Since 2010 , there has been an increase in acreage at a rate of $0.4 \%$ per year. The yield, despite a high BCP, is significantly inferior to the grain yield in the Krasnodar territory, by 2.7 times. However, there is a steady trend towards increasing yields over the past eighteen years, with an annual yield increase of $8.4 \%$.

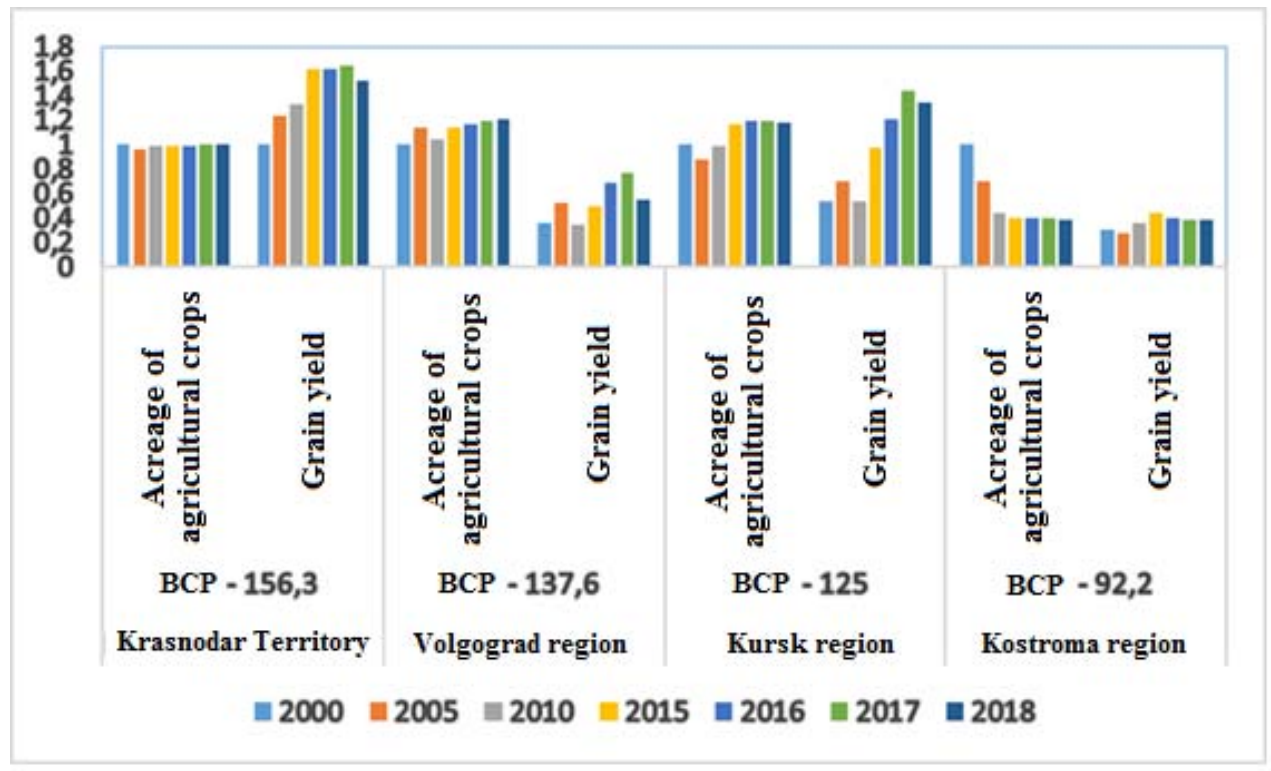

Fig. 1. Dynamics of changes in acreage and grain yield depending on the bioclimatic potential

Next, we will consider two regions in the Federal district that allowed a decrease in acreage - the Central FDt, the Kursk and Kostroma regions. In the Kursk region, the BCP is quite high - 125 points. Acreage in the Kursk region increased by $18.5 \%$ by 2018 , a decrease was allowed in the period from 2000 to $2005-12.2 \%$, and since 2005 there has been an increase in acreage at a rate of $0.4 \%$ per year. The yield is quite high for BCP and ranges from 34 to $50.4 \mathrm{c} /$ ha over the past five years. In the Kostroma region (BCP 92.2 points), the acreage decreased by 2.5 times, by 2005 the acreage decreased by $29.6 \%$, by 2010 , compared to 2005 , by $37.9 \%$, by 2015 , compared to 2010 , by $9.3 \%$, and only since 2015 the availability of acreage has almost stabilized (see Fig.1). The yield in the Kostroma region is quite low, 
below the regions with similar indicators of $\mathrm{BCP}$, such as the Vologda region, Perm region, Sverdlovsk region, Tomsk and Amur regions.

Further, in my research, I would like to deduce the dependence of changes in acreage on the bioclimatic potential. The results of the study are shown in Fig. 2.

According to the data from Fig. 2 we can draw the first conclusion that the increase in acreage is observed only in Federal districts with BCP over 137 points (the exception is the Far Eastern FD). In Federal districts with a BCP below 137 points, a decrease in acreage is allowed, and the lower the BCP, the greater the decrease in acreage, both in $\%$ terms and in absolute values (Northwestern and Siberian FD). For a more accurate analysis of the dependence of changes in acreage on BCP, consider the dynamics of changes in acreage by region. For this purpose, the dynamics of changes in acreage in 63 regions of Russia that have different bioclimatic potential and are actively engaged in agricultural production are considered and analyzed. The results of the study are presented in table 3.

Table 3. Dynamics of changes in acreage depending on the bioclimatic potential

\begin{tabular}{|c|c|c|c|c|}
\hline \multirow{2}{*}{ Bioclimatic potential } & \multicolumn{3}{|c|}{ Acreage movement } \\
\cline { 2 - 5 } & \multicolumn{2}{|c|}{ Increase } & \multicolumn{2}{c|}{ Decrease } \\
\cline { 2 - 5 } & $\begin{array}{c}\text { Absolute value, } \\
\text { thousand ha }\end{array}$ & $\%$ & $\begin{array}{c}\text { Absolute value, } \\
\text { thousand ha }\end{array}$ & $\%$ \\
\hline $126-157$ points & 1483.7 & 8.5 & 171.4 & 6.2 \\
\hline $110-126$ points & 1033.9 & 9.9 & 2169.6 & 20.1 \\
\hline $100-110$ points & & & 4699.6 & 27.9 \\
\hline $86-100$ points & 622.5 & 94.4 & 3085.7 & 34.3 \\
\hline
\end{tabular}

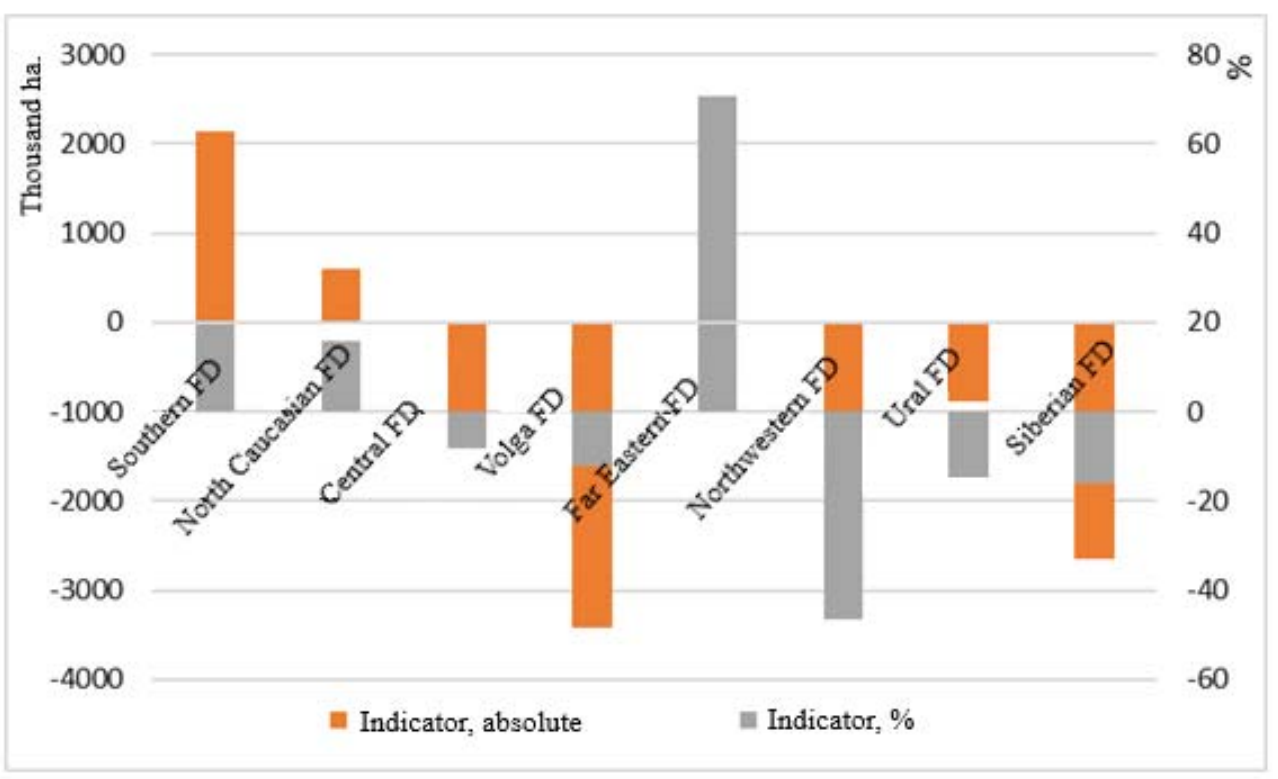

Fig. 2. Changes in the acreage of Federal districts depending on the bioclimatic potential.

Bioclimatic potential: Southern FD - 145.4 points; North Caucasian FD - 137.6 points; Central FD - 114.5 points; Volga FD - 112.6 points; Far Eastern FD - 108.9 points; Northwestern FD - 105.7 points; Ural FD - 97.7 points; Siberian FD - 94.6 points. Based on the study and data from table 3, the following conclusions can be drawn:

1. With BCP of $126-157$ points, the increase in acreage is $42.7 \%$ of the increase in acreage for the period from 2000 to 2018 , the decrease in acreage in this BCP range is $1.7 \%$ 
of the total decrease in acreage for the specified period. Acreage increased in the Belgorod and Voronezh regions of the Central FD, in the regions of Southern and North Caucasus FD, with the exception of the Astrakhan region, the Kabardino-Balkarian Republic, the Karachayevo-Cherkessian Republic, the Republic of North Ossetia - Alania, also decreased the acreage in the Kaliningrad region of the Northwestern FD.

2. With BCP of $110-126$ points, the increase in acreage was $32.9 \%$, and the decrease in acreage was already $21.4 \%$ of the total decrease in acreage. This BCP range includes the regions of the Central FD, the Volga FD, and the Far Eastern FD.

3. With BCP of 100-110 points, there was only a decrease in acreage and accounted for $46.4 \%$ of the total decrease in acreage. Regions with this BCP indicator are in every Federal district except the Southern FD. For example, the following can be cited: Ivanovo region (BCP - 100), a decrease of 196.8 thousand ha, the Republic of Bashkortostan (BCP 109.4), a decrease of 791.5 thousand ha [19].

4. With BCP of 86-100 points, there was an increase in acreage in the Amur region (Far Eastern FD) [20] - 19.8\%, the decrease was 30.5\%, mainly in the regions of the Ural and Siberian FD.

\section{Conclusions}

Land in regions with a low $\mathrm{BCP}$ (86-110 points) is withdrawn from agricultural turnover. The share of these regions in the total amount of unused land is about $80 \%$. It should be noted that despite the decrease in acreage, including under grain and forage crops, the production of the main types of agricultural products is not reduced. For example, grain production increased 1.85 times over 19 years and reached 121200 thousand tons, while the area under grain crops decreased by 805 thousand ha during this period. Milk production increased by 1.3 times, with a decrease in the number of cows almost twice, with a decrease in the area under forage crops by $59.5 \%$. This became possible as a result of an increase in grain yield by 1.7 times, and cow productivity by 2.7 times.

The main criterion that determines the need to introduce abandoned land into agricultural circulation is to ensure food security in Russia. If we achieve the indicators that ensure the state food security and the effective management of agricultural production, we can develop the export of agricultural products. When introducing abandoned land into agricultural circulation, it is necessary to consider the costs of commissioning and the expected effect of agricultural land being put into turnover. Therefore, the means, timing and directions for introducing abandoned land and methods for evaluating the effectiveness of the land being introduced are important.

It is equally important to take into account the agricultural machinery park used for this purpose, its structure, and the possibility of using this Park in agricultural production technologies when evaluating the efficiency of land use [21].

\section{References}

1. Federal State Statistics Service. Agriculture, hunting, and forestry, https://rosstat.gov.ru/

2. Regions of Russia. Socio-economic indicators 2002, https://rosstat.gov.ru/

3. Regions of Russia. Socio-economic indicators 2005, https://rosstat.gov.ru/

4. Regions of Russia. Socio-economic indicators 2010, https://rosstat.gov.ru/

5. Regions of Russia. Socio-economic indicators 2015, https://rosstat.gov.ru/

6. Regions of Russia. Socio-economic indicators 2019, Rosstat. Moscow, 1204 (2019) 
7. V.Ya. Uzun, The necessity and mechanisms of involvement of abandoned agricultural land in Russia in the turnover during the reform period (speech at the conference in the HSES, 2011) https://docviewer.yandex.ru/view/58032475/ 09.10.20

8. V. Saraykin, V. Uzun, R. Yanbykh, Russian economic development, 21(5), 40-43 (2014)

9. A.D. Kleshchenko, B.A. Chernyakov, O.D. Sirotenko, V.N. Temnikov, I.B. Uskov, V.A. Romanenkov, D.I. Rukhovich, Bioclimatic potential of Russia: adaptation measures in a changing climate, Ministry of Agriculture of the Russian Federation, All-Russian Research Institute of Agricultural Meteorology of the Russian Meteorological Service of the Institute of the USA and Canada of the Russian Academy of Sciences, Research Institute of Agrochemistry named after D.N. Pryanishnikov of the Russian Academy of Agricultural Sciences, Soil Institute named After V.V. Dokuchaev of the Russian Academy of Agricultural Sciences, Agrophysical Institute of the Russian Academy of Agricultural Sciences (Moscow, 2008)

10. A.L. Ivanov, A.A. Zavalin, M.S. Kuznetsov, V.A. Zakharenko, I.P. Svintsov, A.I. Karpukhin, V.A. Isaev, G.G. Gulyuk, P.A. Chekmarev, P.A. Efanov, V.I. Kiryushin, N.B. Khitrov, A.N. Kashtanov, B.F. Aparin, I.I. Karmanov, D.S. Bulgakov, E.N. Molchanov, V.A. Rozhkov, M.S. Simakova, D.I. Rukhovich, etc. Agroecological state and prospects of using Russian lands that have been eliminated from active agricultural turnover, Ministry of Agriculture of the Russian Federation, Russian Academy of Agricultural Sciences (Moscow, 2008)

11. L.N. Ermakova, N.I. Tolmacheva, E.A. Bezmaternykh, Geographical Bulletin, 2(13), 52-58 (2010)

12. S.V. Krasheninnikov, Agricultural and land law, 5(185), 103-106 (2020)

13. S.V. Shchukin, A.I. Golubeva, V.I. Dorokhova, A.N. Dugin, Bulletin of the agroindustrial complex of the upper Volga region, 1(41), 87-98 (2018)

14. I.I. Goldina, V.S. Zorkov, Role of technical means and resource-saving technologies in the development of abandoned lands, In the collection: from inertia to development: scientific and innovative support for the production and processing of crop production. Resource-saving technologies, technical means, and a digital platform of agro-industrial complex. Collection of materials of the scientific and practical conference, 156-159 (2020)

15. J.C. Howard, E. Cakan, K.P. Upadhyaya, International Journal of Food and Agricultural Economics (IJFAEC), 4(2), 1-10 (2016)

16. Q. Xu, R. Sarker, G. Fox, D. McKenney, International Journal of Food and Agricultural Economics (IJFAEC), 7(1), 1-17 (2019)

17. Climate services for the agro-industrial complex, cc.voeikovmgo.ru 10.10.20

18. V.S. Semenovich Russian non-black earth soil: putting abandoned lands into turnover, improving the efficiency of using all its lands and export relations (on the example of the Central non-black earth soil of the Russian Federation), 22, 286-288 (2017)

19. I.R. Vildanov, I.M. Yaparov, A.F. Gumerov, R.Z. Khizbullina, Bulletin of the NorthEastern Federal University n.a. M.K. Ammosov, Series: Earth Sciences, 2(14), 50-60 (2019)

20. V.S. Krylov, V.A. Bayunov, Agro-industrial complex: Economics, management, 10, 5159 (2019)

21. G.A. Iovlev, Economics of agriculture of Russia, 11, 64-71 (2019) 